\title{
NURSING EDUCATION AT THE BRAZILIAN NEW STATE ERA: THE CASE OF THE MEDALHA MILAGROSA SCHOOL
}

\author{
Fatima Maria Da Silva Abrãoํㅜ, Tânia Cristina Franco Santos², Amanda Regina da Silva Góis ${ }^{3}$, Rezilda Rodrigues \\ Oliveira ${ }^{4}$
}

\footnotetext{
${ }^{1}$ Ph.D. in Nursing. Professor Faculdade de Enfermagem Nossa Senhora das Graças, Universidade de Pernambuco. Recife, Pernambuco, Brazil. E-mail: fatimabrao@terra.com.br

${ }^{2}$ Ph.D. in Nursing. CNPq Scholarship student. Rio de Janeiro, Rio de Janeiro, Brazil. E-mail: taniacristinasfc@terra.com.br

${ }^{3}$ M.Sc. in Nursing. Programa de Pós-Graduação em Enfermagem, Universidade de Pernambuco, Universidade Estadual da Paraíba. Recife, Pernambuco, Brazil. E-mail: amanda_regina137@hotmail.com

${ }^{4}$ Ph.D. in Political Science. Professor, Universidade Federal Rural de Pernambuco. Recife, Pernambuco, Brazil. E-mail: rezilda.rodrigues@ gmail.com
}

\begin{abstract}
The aim of this study was to analyze how the creation of the Medalha Milagrosa Nursing School took place in 1945 . This is a socio-historical study that uses an analytical strategy anchored in Pierre Bourdieu's thought. Primary and secondary sources were used. As a result, the central role of the New State (Estado Novo) and its historically authoritarian interpenetration in the societal and economic spheres are discussed, as well as the process through which the field of forces and struggles was constructed by the players during the movement to create this school. In the organizational and bureaucratic field, disputes between the State, the Church, and the academic environment are observed. There is evidence related to the innovation that this school meant in the fields of health and education, as well as to actions taken by the players who created it according to the patterns of modern nursing.
\end{abstract}

DESCRIPTORS: History of nursing. Academic institution. State

\section{ENSINO DE ENFERMAGEM NA ÉPOCA DO ESTADO NOVO: O CASO DA ESCOLA MEDALHA MILAGROSA}

RESUMO: Este artigo tem por objetivo analisar como ocorreu a criação da Escola de Enfermagem Medalha Milagrosa, em 1945. Trata-se de estudo sócio-histórico que utiliza estratégia de análise ancorada no pensamento de Pierre Bourdieu. Foram utilizadas fontes primárias e secundárias. Como resultado, discute-se a figura central do Estado Novo e sua interpenetração historicamente autoritária na esfera societal e econômica, bem como o processo no qual se configura o campo de forças e de lutas construído pela ação de agentes no movimento de criação dessa escola. No campo organizacional e burocrático são observadas disputas entre o Estado e a Igreja e o meio acadêmico. Há evidências relacionadas à inovação que essa escola significou no campo da saúde e educação, bem como à atuação dos agentes que a criaram nos moldes da enfermagem moderna.

DESCRITORES: História da enfermagem. Instituições acadêmicas. Estado.

\section{ENSEÑANZA DE ENFERMERÍA EN LA ÉPOCA DEL ESTADO NOVO BRASILEÑO: EL CASO DE LA ESCUELA MEDALHA MILAGROSA}

RESUMEN: Este artículo objetiva analizar cómo se dio la creación de la Escuela de Enfermería Medalha Milagrosa, en 1945. Esto es un estudio socio-histórico que utiliza una estrategia de análisis anclada en el pensamiento de Pierre Bourdieu. Se utilizaron fuentes primarias y secundarias. Como resultado, se discute la figura central del Estado Novo y su interpenetración históricamente autoritaria en la esfera societal y económica, así como el proceso mediante el cual se establece el campo de fuerzas y de luchas construido por la acción de agentes en el movimiento para crear esta escuela. En el campo organizacional y burocrático, se observan disputas entre el Estado y la Iglesia y el ambiente académico. Hay evidencias relacionadas con la innovación que esta escuela significó en el campo de la salud y la educación, así como con la actuación de los agentes que la crearon según los moldes de la enfermería moderna.

DESCRIPTORES: Historia de la enfermería. Instituciones académicas. Estado. 


\section{INTRODUCTION}

Taking as the starting point the politicalinstitutional and organizational repercussions that arose from the New State (Estado Novo) practice and its despotic and infrastructural rule, the focus is on the creation of the Medalha Milagrosa Nursing School in 1945, at the end of President Vargas' first administration.

Using the reference to support this study, carried out in the light of a socio-historical process, the aim was to combine two mutually dependent strategies of analysis: one with an emphasis on the state-centric approach, which appoints the pivotal role of the State as the key mentor and articulator of social-economic development, leaving room for the interpretation of the meaning of historically authoritarian State interpenetration in Brazilian society. ${ }^{1}$

The focus is on the arguments related to a strong State, which concentrates its power and succeeds in imposing its intervention on society. ${ }^{2}$ In the New State, this also takes place with a focus put on education and the need for educational reform, which implementation suffered under the strong influence of the authoritarian regime led by Getúlio Vargas. ${ }^{3}$

The second strategy of analysis falls on the process that constitutes the field of forces and struggles brought up by the agents involved in the movement for creating and operating the Medalha Milagrosa Nursing School. The implications of such studies consist of trying to understand the social dynamics promoted by the agents that occupy a given space, guided by environmental interactions and actions depending on an organizational field under construction.

Therefore, the position that certain agents occupy in a given social space is taken into consideration, although it can be relative. The social space, in turn, has several dimensions formally construed and based on differentiation and distribution principles, which provides to the agents or group of agents the ability to be the force or power holders in this realm. ${ }^{4}$

The Medalha Milagrosa Nursing School case study shows the links between the political-institutional plan and the organizational as well. On one hand, it addresses the New State context; on the other hand, it tries to identify the new insights of the agents working in the institutional set-up of environments and power, especially in their ability to be holders, not only at the organizational level. This is because, regarding the organizational field, it is necessary to transcend and reach out to the social context. . $^{5}$

Reflection on the topic acknowledges that it refers to a strong and autonomous State, ${ }^{7-8}$ which is the approach that almost always arises from studies conducted in countries marked by authoritarianism, such as Brazil. In developed capitalist countries, the lines of empirical research tend to concentrate on the State as the actor and the State as an institutional structure. ${ }^{9}$

A strong State, such as the New State, is the one that knows how to impose the rules of the political game with the society that it tries to rule, without necessarily using the coercive measures placed at its disposal, but by means of "incentives" and alternative resources to enhance its own positions and obtain approval in the social-environmental context. ${ }^{10}$

The analysis carried out here is substantiated in the light of the studied context, which identifies the increasing state autonomy necessary to deal with increasingly more complex societies and, at the same time, investigates the mechanisms that lead to the creation of institutions that will provide support for this structure in the process of development. ${ }^{11}$

This distinct point can be illustrated in two types of state power: despotic power and infrastructural power. ${ }^{10}$ These interrelated powers demonstrate the logistic and political mode of interpenetration of the State in the material base of the society, through the imposition of strategies restricted to the democratic game, such as the case of the New State. The greater the despotic power imposed infrastructurally by the State, in light of the social actors, the greater the dimension of its authoritarianism will be. ${ }^{10}$ Such degrees and variations lead to different political-institutional repercussions, which help us to understand how certain institutions were created, even in the face of repression, and how the cooperation of objective forces in action was obtained. Such issues are thoroughly examined, since they co-substantiate the study presented here.

The New State, which was in force from 1937 to 1945 , under the command of Getúlio Vargas, typifies the arguments already mentioned, especially by its authoritarian and dictatorial nature, ${ }^{11}$ exemplified by the granted Constitution that extinguished the political parties and dissolved the National Congress, ${ }^{12}$ the State Assemblies, and the Municipal Chambers.

The New State dictatorship was established through a coup d'état that implemented an authoritarian regime, whose main characteristics were worship of the nation, criticism against democracy, 
hostility to Marxism, admiration of virtues, ritualistic demonstration of emblems and role models, obedience to a leader, and media control. ${ }^{13-14}$

Consequently, the new social order, in accordance with Fascist ideology, demanded a series of symbolic and political strategies for maintaining the new regime, at the same time that it reinforced the idea that liberal democracy was totally annihilated.

Getúlio Vargas' personal power was also consolidated through strategies aimed at personifying the myth with the help of the State. Therefore, in 1939 the Press and Propaganda Department (DIP) was launched to boost the worship of the State and the image of Getúlio Vargas, ${ }^{14}$ which extended until his leaving power. Parades, manifestations, and radio shows were organized to carry out the celebrations, on the $19^{\text {th }}$ of April, of the dictator's birthday, in order to praise his personal qualities ${ }^{4}$ and guarantee social dissemination by means of symbolic mechanisms of manipulation and coercion, ${ }^{15}$ mediated by tacit recognition of authority. When the individual understands that those who exercise authority over him have the right to do so, this contributes to the addressee's recognition of the consecrated person as being the spokesperson authorized to speak on behalf of the group he controls.

During the New State intervention, education regarded as fundamental values the cult of nationality, discipline, morality, and work, among others. The pedagogic tenets, at that time, were considered completed and the educational ideal for labor was to "learn by doing". ${ }^{16}$

In the healthcare field, ${ }^{17}$ public policy changes that took place in the first Vargas administration (1930-1945) were prominent as far as aspects of advancement, such as an infrastructural base with the creation of the Education and Public Health Ministry (MESP), in November of 1930, in response to the expectations of the First Republic sanitarian movement. ${ }^{18}$

Without a doubt, this era left its mark as the period of public health in Brazil. In charge of the MESP (1934-1945), Gustavo Capanema centralized and professionalized the health care system and linked it to the Nationalist ideology of a strong and authoritarian State $^{17}$ as part of a reform process that he carried out. From 1937 the dictatorship regime was established.

It was only in 1947, however, that discussions on the public healthcare field were resumed with the Brazilian Hygiene Congress, which had been suspended since 1930. The last Brazilian Hygiene Congress had taken place in 1929, in Recife-PE, in its fifth edition. There was already a movement for the creation of a nursing school, affiliated with the Hospital do Centenário, which had not been implemented. In 1938, this hospital suffered an intervention.

Then, in 1945, the first school for "high standard nurses" was created, in conformity with the creation of Medalha Milagrosa Nursing School, link to Hospital Pedro II. ${ }^{19}$

It is worth investigating what it meant to the healthcare field to create a school in Recife-PE, at the end of the New State, comparable to the Escola de Enfernagen Anna Nery (EEAN). The latter was created in 1923 in the city of Rio de Janeiro. In 1945, it had already graduated its $20^{\text {th }}$ class and experienced the same reality of a dictatorial regime. The question, then, is: what were the repercussions of the New State on nursing education in Pernambuco, especially in the case of the Medalha Milagrosa Nursing School?

Capanema's Reform structured industrial education, reformed commercial education, and created the National Service of Industrial Training (SENAI), based on the Organic Laws of Education, ${ }^{20}$ which had an impact on nursing. With the Constitution of 1937, the EEAN was included in the university system imposed at that time, and was incorporated into the Universidade do Brasil, currently the Universidade Federal do Rio de Janeiro (UFRJ). Its characterization as an institution of complementary education emerged with Law n. 452/1937, under the direction of the North American nurse Bertha Lucille Pullen. ${ }^{21}$

Later, in 1945, the EEAN came to be regarded as an education unit, through Decree-Law n. $8.393 / 1945$, under the direction of Laís Netto dos Reys, who became the first director graduated at EEAN.

In view of the contextualization of the subject, and according to issues raised by the study, the objective, following the political-institutional and organizational repercussions generated by New State's policies and its despotic and infrastructural power, is to analyze how the creation of the Medalha Milagrosa Nursing School took place in 1945.

\section{METHOD}

This is a social-historical study that found in Pierre Bourdieu's thought the theoretical framework for analysis and interpretation, with the notion of field and symbolic power. The field structure and key positions are defined by the type of capital and 
the rules of the game, ${ }^{4}$ while the field of power takes place in the space of force relations among different types of capital. Comparative history is a research strategy in this study; it is important to note that this approach found its origin in Marc Bloch, who, in 1930, introduced his concept of comparativism..$^{22-23}$

To apply the comparative method in the human sciences framework consists of searching for, in order to explain them, the similarities and the differences that present two series of an analogous nature, drawn from distinct social spheres. For Marc Bloch, the comparison still performs important functions, such as to research and explain specific and general aspects of each phenomenon and to help gain an understanding of the "causes" and "origins" of the phenomena. ${ }^{24}$

The data of this study were collected from August 2011 to July 2012. Primary sources were used, such as written documents, the Constitution, laws, decrees, reports, and newspapers from the archives of the Center for Research and Documentation of Brazilian Contemporary History, Fundação Getúlio Vargas, EEAN, UFRJ, the Fundação Joaquim Nabuco, and the Escola de Enfermagem Nossa Senhora das Graças of Universidade de Pernambuco; the secondary sources refer to Brazilian historiography from Vargas's Era and to nursing education.

The data were analyzed after collecting and organizing the primary sources, carried out by comparing the similarities and differences of the social phenomena to be investigated. For interpretation we used the theory of social capital, by Pierre Bourdieu, which can be taken as what the agents do every time, ${ }^{4}$ constituting a movement similar to the order of things in the field.

To better understand the field and its analysis, attention is drawn to the strategy of a state-centered view, which configures the field of forces and struggles related to the studied phenomenon.

The results enable the visualization of the agents - a term used by Bourdieu - in the field, their symbolic fights, the strategies adopted in the field, and how they organize themselves, thus favoring the infrastructural base in health and education that had an impact on nursing education.

Regarding ethical aspects, although the study did not involve human beings, it was approved by the Ethics Research Committee Centro de Saúde Amaury de Medeiros in 2005, because it is linked to a project on the early days of professional nursing that took place from 1922 to 1945.

\section{RESULTS AND DISCUSSION}

Placing the case of Medalha Milagrosa School into the New State context, it is extremely important to describe how it was established and what it stood for in the field of health care and education, amid the process of its movement towards creation. On the one hand, the roles that the State and the Church played in this process made the social functions known and, later, legitimated.

In this context, the EEAN places itself as the "official standard school", because the other schools in the country are equipped according to it ${ }^{*}$. As for the Medalha Milagrosa School, it received its federal certification in 1949, four years after its creation.

\section{The Medalha Milagrosa Nursing School: brief history}

Nursing education in Pernambuco had its origin at Hospital Pedro II, where the first childbirth class was given, in 1880, for female and male nurses. It was at Hospital Pedro II that isolated forms of school organization took place, although it was not yet considered a field of nursing, which was consolidated decades later.

This innovative spirit found the right place on August 1, 1945, when Medalha Milagrosa Nursing School held its first classes, with the presence of the members of Santa Casa de Misericórdia and civil, academic, ecclesiastical, and clinical-surgical authorities.

The Medalha Milagrosa Nursing School found its headquarters at Hospital Pedro II under the direction of the São Vicente de Paulo Sponsors Association, with Sister Chabas as the Mother Superior and graduated Sister Ana Maria Sarmento as the instructor. ${ }^{25}$ The admission examination of the first class took place on July 10, 1945, when the examination board met, formed by Sister Rodrigues, the president; Sister Marques, first examiner; Sister Josefa Madureira, second examiner; and Sister Chabas, the director.

From the admission examination, 11 students were approved, after written and oral exams, on the same day as the abovementioned inaugural class, ${ }^{25}$ marking the beginning of Medalha Milagrosa Nurs-

The equation obeyed the Brazilian Decret n 20.109, 15 Jun 1931, revoked in 17 Sep 1955, Brazilian Law n 2.604. 
ing School activities, in which the Minutes of the creation were attended by Dr. Fernando Simões Barbosa. Previously, it must be emphasized, he also participated in the movement for the creation of a school for nurses, linked to a reference hospital, jointly with Benedictine Pedro Roeser, without achieving success.

In the case of the Medalha Milagrosa School, everything indicates that Fernando Simões Barbosa was not only involved with its creation, but also joined the order of professors. Moreover, as an agent in the healthcare and education fields, it is known that he was the founder of a nursing school, the reason why this process was enriched with his symbolic capital, through his prestige and social status.

The Church played an important role as institutional agent due to its position in the fields of health care and education, with the attendance of Archbishop of Olinda and Recife, Dom Miguel de Lima Valverde, who presided over the Medalha Milagrosa Nursing School's inaugural session, and affixed the first signature on the Minutes of the creation on August 1, 1945. On that day, the Medalha Milagrosa Nursing School organizing commission also met, with the presence of Dr. Barros Lima, then the Hospital Assistance Department Director; representatives of the Santa Casa de Misericórdia Administrative Board of Recife; professors of the Medical School; and members of the middle class of Recife. The medical class was represented by Prof. Homero Marques, who made the opening speeches and highlighted the medical-social importance of the creation of this school. ${ }^{25}$

From an operational point of view, the classes at Medalha Milagrosa Nursing School started taking place on a regular basis, offering technical, theoretical, and practical duties more efficiently, with students receiving essential learning in nursing techniques and sterilization, surgical equipment, operating room protocols, and patient management in general.

Compared to EEAN, the Medalha Milagrosa Nursing School adopted similar rituals, such as: the nursing cap ceremony and the use of lamps during graduation, which occurred a posteriori. Over the years, the teaching had been built according to a professional identity already in place, which contributed to the formation of an emerging field at the time, thus allowing the possibility of sharing beliefs and values. The cognitive and normative bases were present in this process of forming nursing professionals.

The analysis shows that the Medalha Milagrosa Nursing School, since the beginning, has consistent- ly applied the values and norms of the educational field identified with the agents that stood out in the organizational field of pre-training for nursing, ${ }^{5,19} \mathrm{a}$ topic that will be discussed in the next section, taking into account that the configuration for the school organization itself was linked to the Medical School, indicating the presence of the academic world, as well as the current hospital model.

Although the Church had exerted a strong influence as the school's sponsoring agent, suffice it to say that Hospital Pedro II, where it was established, was maintained by Santa Casa de Misericórdia and received public subsidies from the State ${ }^{19}$ since the beginning of the $20^{\text {th }}$ century. Therefore, its role in the studied context should be mentioned, with infrastructural bases prior to the school creation, which was born through political and educational alliances that deserve attention.

\section{Health and Education Organizational Field: the role of the State and the Church}

The Medalha Milagrosa Nursing School, can be considered the first professional nursing school in Pernambuco, which provides an opportunity to focus on the background of its institutionalization. ${ }^{26-27}$

The Church, played a key role in this process, bringing in a French nurse, in 1943, to manage Hospital Pedro II; she observed the nursing practice conditions provided to the patients and noted the need to create a nursing school. The nurse, Sister Germaine Chabas, belonged to Order of São Vicente de Paulo, whose Sisters of Charity were already working in Hospital Pedro II.

In Pernambuco long before, in 1922, the Hospital do Centenário Sponsoring Association was launched, bringing together philanthropic and mobilization actions for a model hospital, which would have a favorable institutional environment for the struggle to create a nursing school.

The Hospital do Centenário was inaugurated in 1925, with State subsidies and under the influence of the medical class, designed to assist the population and improve medical education. Marked by the innovative nature of its practice, the Hospital do Centenário tried to retain German and English nurses in its administration. ${ }^{19-28}$

More than a decade later, already under the New State, trying to promote reform in the State health care service, the expropriation of Hospital do Centenário took place, wherein state power was imposed, ${ }^{8}$ with the intention of providing service to the State Public Service Welfare Institute, intended 
for its members. This action went against the medical class, which had just allowed the arrival of nurses to manage the Hospital do Centenário and, with their innovative ideas, managed to obtain support from the society.

Although this happened during the New State, there are elements that indicate repercussions in nursing, which suffered the influence of this dispute, and finally managed to revive when the power play in its favor was reversed by the Church. The counterpoint of this analysis lies in the action of the agents responsible for the creation of the Medalha Milagrosa Nursing School.

The Medalha Milagrosa Nursing School started operating without direct official help from the government, and it was up to the Church to provide the predominant symbolic capital in this power play. On the other hand, as the institutional agent, the State played the controlling role, with its norms and values shared by the agents, and this was consolidated through leveling, without coercion, but through adherence and identification along the lines of a standard school, fulfilled by maintaining the rituals. Although no longer official, however, the schools at that time had to fulfill the requirements of the standard school, keeping the cap and badges rituals, among other symbols. Then, the Medalha Milagrosa Nursing School was recognized by decree n. 27.281 of September 30, 1949, already under the name Nossa Senhora das Graças Nursing School, after the Dutra administration passed Law n. 775 on August 6, 1949, that ruled on the standards of nursing education in the country.

During this period, even with Getúlio Vargas no longer in power, it is possible to point to some small-scale political-institutional and bureaucratic repercussions presented in the movement for the creation and struggle of the agents in the healthcare and educational field.

The formation of a professional nursing organizational field in Recife underwent changes related to the expansion that occurred with the inclusion of one more school, this time on the part of the Dutra administration with Decree n. 1.702 on June 25, 1947, which created the Nursing School of the State of Pernambuco, designed for technical-professional nursing education, with the aim of preparing "high standard nurses" for public health and hospital care services. ${ }^{19}$

With this move, the State took over nursing education, and this school was inaugurated in the Hospital do Centenário only in 1950, linked to the Medical School, in a different time from the Nossa
Senhora das Graças Nursing School, whose origin was associated with the initiatives of the Church in the healthcare and educational field.

Under the poor conditions that the school found itself in its efforts to meet societal demands, it was up to the Church, through Santa Casa de Misericórdia, to donate a lot in the open area of Hospital Pedro II for the school. This occurred due to the great deal of interest by the Church and the enrollment demands, when it became clear in the historical speech of what was expected that this exemplary undertaking would bring, keeping in mind the construction of a building. The praises to the school and its innovative work in the healthcare field are explicit in the speech: "For all the reasons, the new School is worthy to be praised and supported with the help of official and private initiatives, from which these organizations must not be disregarded". ${ }^{25: 2}$

There is the prediction of building a scientific capital on the part of the Medalha Milagrosa Nursing School, whose origin deserves comparison with the legacy of Florence Nightingale, identified with modern high-standard nursing. This, in turn, was implemented by Ethel Parsons during Carlos Chagas' sanitary reform, which sparked the arrival of a group of North American nurses, members of the Parsons' Mission, in the city of Rio de Janeiro in 1921. The referred to mission worked simultaneously to set up a teaching hospital, organize a nursing school, and establish a public health nursing service..$^{29-30}$

\section{FINAL CONSIDERATIONS}

This study addresses the advent of nursing education in Pernambuco, in the context of the creation of the Medalha Milagrosa Nursing School, at the end of Vargas' first administration, with emphasis on the health and educational field. The results enable us to say that its creation was, at the time, a groundbreaking movement that evoked earlier institutions as basic references so that the work of the agents involved could succeed.

There is evidence related to the innovation that this school represented, observed in the formation of a nursing field, still under construction, that allowed relating it to the symbolic aspects of the agents in the given context, starting with the findings on the force behind modern nursing at the time.

The analysis raises political-institutional and organizational questions resulting from the New State actions; however, it respects the fact that the creation of the Medalha Milagrosa Nursing School 
took place when the dictatorial government of Getúlio Vargas was coming to an end, by the end of 1945. The observed movement requires the addition of the repercussions resulting from actions and deeds demanded by the Dutra administration, which took over from the Vargas administration, indicating a more democratic transition that started to be unleashed in the country.

The data suggest the role played by a strong State, but one that represents itself from the infrastructural standpoint, with a special focus on the subsidies that not only the Medalha Milagrosa Nursing School received, but also those provided to other institutions that work in the same field of formation. This fact should not be overlooked in the analysis of the social dynamics in which the interventions of the agents who occupy the spaces that allow maneuvers in different directions occur, affecting disputes or forming alliances in order to advance towards its purposes.

The analysis strategy, focused on the institutional configuration of the environments and power necessary for creating the Medalha Milagrosa Nursing School demonstrates an admiration for the legacy virtues of professional formation of nurses, based on the best they had to offer, on what they had to create, and on the high standard in the educational field, including the reproduction of symbolic rituals of legitimation; thus, it is not surprising that the new school was able to raise social support and earning praise since its early days, indicating evidence of the generation of scientific capital that grew from cognitive and normative bases, which are materially visible through the accomplishments that arise from the analysis: classes; examining boards; entrance admissions; enrollments; and turnout of people interested in enrolling.

In the studied events, observations were made regarding the representations of the members of the Church, physicians, and professors moving favorably towards the expansion of the field in Pernambuco, with the emergence of another educational institution, the Nursing School of the State of Pernambuco, which also must be taken into account.

The Church, in turn, played such an important role that it exceeded the strength of the State itself, because it was under its auspices that the Medalha Milagrosa Nursing School came into existence, and it is not an exaggeration to say that the symbolic capital upon which it was built and which predominated in the educational and healthcare field comes from its power to carry forward the accomplishments of the agents who nurtured their dreams yet to come true.
Will the Church be able to rely on philanthropic allies from the medical class linked to Hospital Pedro II, and at least the Order São Vicente de Paulo, which supports the formation of teaching staff in technical and managerial functions, without which the Medalha Milagrosa Nursing School operation would be at risk?

Finally, it is asserted that this set of forces, with which such agents articulate, provides support to the kind of repercussions that had a major influence in nursing education, suggesting that this was the path taken by the agents who acted for the formation of an emerging field at the time, when it was possible to envision the sharing of values that would underpin the infrastructure basis required by Medalha Milagrosa Nursing School at the end of 1945.

\section{REFERENCES}

1. Keinert TMM. Administração pública no Brasil: crises e mudanças de paradigmas. $2^{\mathrm{a}}$ ed. São Paulo: Annablume; 2007.

2. Bresser-Pereira LC. Sociedade civil: sua democratização para a reforma do Estado. In: Bresser-Pereira LC, Wilheim J, Sola Lourdes S, organizadores. Sociedade e Estado em transformação. São Paulo (SP): Ed. Unesp; 1999. p. 65-72.

3. Bomeny HMB. Três decretos e um ministério: a propósito da educação no Estado Novo. In: Pandolfi D, organizador. Repensando o Estado Novo. Rio de Janeiro (RJ): Ed. FGV; 1999. p.137-66.

4. Bourdieu P. O poder simbólico. Rio de Janeiro (RJ): Bertrand Brasil; 1989.

5. Scott WR. Institutions and organizations. Thousand Oaks, CA (US): Sage; 1995.

6. Dimaggio $P$, Powell $W$. The iron cage revisited: institutional isomorphism and collective rationality in organizational fields. In: Powell W, Dimaggio P. The new institutionalism in organizational analysis. Chicago, IL (US): University of Chicago Press; 1991. p. 63-82.

7. Evans P. Predatory, developmental, and other apparatuses: a comparative political economic perspective on the Third World State. Sociological Forum. 1989; 3(4):561-87.

8. Migdal JS. Strong States, weak States: power and accommodation. In: Weiner M, Huntington SP, organizadores. Understanding political development. Boston, MA (US): Little Brow; 1987. p. 391-434.

9. Skocpol T. Bringing the State back. In: Evans M, Skocpol T, organizadores. Strategies of analysis in current research. Cambridge (UK): Cambridge University Press; 1985. p. 3-35.

10. Mann M. The autonomous power of the State: its origins, mechanisms and results. European J Sociol. 1984; 25(2):185-213. 
11. Souza, MCC. Estado e partidos políticos no Brasil (1930 a 1964). São Paulo (SP): Alfa-Omega; 1990.

12. D'Araújo MC. O Estado Novo. Rio de Janeiro(RJ): Jorge Zahar; 2000.

13. Naiff DGM, Sá CP, Naiff LAM. A memória social do Estado Novo em duas gerações. Psicol Ciênc Prof [Internet]. 2008 [cited 2015 May 13]; 28(1):110-21. Available from: http://www.scielo.br/pdf/pcp/ v28n1/v28n1a09.pdf

14. Santos TCF, Barreira IA, Almeida Filho AJ, Oliveira AB. The Franco and Vargas dictatorships: implications of the consecration of maternity for nursing. Texto Contexto Enferm [Internet]. 2010 [cited 2015 Oct 23]; 19(2):317-24. Available from: http://www.scielo.br/scielo.php?script=sci_ arttext\&pid=S0104-07072010000200013

15. Camargo A. Carisma e personalidade: da conciliação ao maquiavelismo. In: D' Araújo MC, organizador. As instituições brasileiras da Era Vargas. Rio de Janeiro (RJ): Ed. FGV; 1999. p. 13-33.

16. Pandolphi D, organizador. Repensando o Estado Novo. Rio de Janeiro (RJ): Ed. FGV; 1999.

17. Hochaman G. Reformas, instituições e políticas de saúde no Brasil (1930-1945). Educar [Internet]. 2005 [cited 2015 Oct 23]; 25:127-41. Available from: http:/ / www.scielo.br/pdf/er/n25/n25a09.pdf

18. Santos LAC. O pensamento sanitarista na Primeira República: uma ideologia de construção da nacionalidade. Rev Ciênc Sociais. 1985; 28(2):193-210.

19. Abrão FMS, Almeida MCP. Primórdios da enfermagem em Pernambuco: raízes da pré-institucionalização da formação do campo organizacional (1922-1938). Recife (PE): Ed. UPE; 2007.

20. Fundação Getulio Vargas. Relatório de atividades do MEC (1930-1935) por Gustavo Capanema. Rio de Janeiro (RJ): Centro de Pesquisa e Documentação de História Contemporânea do Brasil; 1946.
21. Baptista SS, Barreira IA. Anna Nava, baluarte da Escola Anna Nery (anos 1940/1970). Esc Anna Nery Rev Enferm [Internet]. 2009 [cited 2015 Oct 23]; 13(3):543-51. Available from: http:/ / www.scielo.br/ pdf/ean/v13n3/v13n3a13

22. Barros JDA. História comparada. Petrópolis (RJ): Vozes; 2014.

23. Barros JDA. História comparada: da contribuição de Marc Bloch à constituição de um moderno campo historiográfico. História Social [Internet]. 2007 [cited 2015 Oct 23]; 13(1):7-21. Available from: www.ifch.unicamp.br/ojs/index.php/rhs/article/ download/207/199

24. Theml N, Bustamante RMC. História comparada: olhares plurais. Rev História Comparada [Internet]. 2007 [cited 2015 Oct 23]; 1(1):1-23. Available from: http:/ / www.hcomparada.historia.ufrj.br/revistahc/ artigos/volume001_Num001_artigo003.pdf

25. Universidade de Pernambuco. Histórico FENSG (etapa 1945-1947). Recife (PE): Faculdade de Enfermagem Nossa Senhora das Graças; 1947.

26. Tolbert PS, Zucker LG. A institucionalização da teoria institucional. In: Cleg S, Hardy C, Walter R, organizadores. Handbook de estudos organizacionais. São Paulo (SP): Ed. 34; 1998. p. 196-219.

27. Abrão FMS, Almeida MCP. Raízes da préinstitucionalização da formação do campo organizacional (1922-1938). Rev Bras Enferm. 2007; 60(1):26-31.

28. Ramos HP. Subsídios para a história da enfermagem em Pernambuco: primeiras pioneiras da enfermagem. Recife (PE): Academia de Medicina; 1977.

29. Barreira IA. Os primórdios da enfermagem moderna no Brasil. Esc Anna Nery Rev Enferm. 1997; 1(1):161-76.

30. Barreira IA. A prática de enfermagem no Brasil: a enfermagem de saúde pública dos anos 20. Texto Contexto Enferm. 1998; 7(1):42-57. 